Terbit online pada laman web jurnal : http://e-journal.sastra-unes.com/index.php/JILP

\begin{tabular}{|c|c|c|}
\hline \multirow[b]{2}{*}{$\begin{array}{c}\text { Fakultas Sastra } \\
\text { Universitas Ekasakti }\end{array}$} & \multicolumn{2}{|c|}{$\begin{array}{c}\text { (JURNAL, ILMIAH LANGUE ANJ PAROLE) } \\
\text { VOLUME } 2 \text { NOMOR } 2\end{array}$} \\
\hline & $\begin{array}{c}\text { ISSN : 2581-0804 } \\
\text { (Media Cetak) }\end{array}$ & $\begin{array}{c}\text { E-ISSN : 2581-1819 } \\
\text { (Media Online) }\end{array}$ \\
\hline
\end{tabular}

\title{
THE STRUGGLE OF A GEISHA IN MAINTAINING HER PRIDE AS SEEN IN ARTHUR GOLDEN'S MEMOIRS OF A GEISHA
}

\author{
Ramiyati Handriyani, Amelia Yuli Astuti \\ Fakultas Sastra Universitas Ekasakti \\ *Corresponding Author: Amelia Yuli Astuti \\ Fakultas Sastra Universitas Ekasakti \\ ameliayuliastuti@gmail.com
}

\begin{abstract}
This thesis is entitled "The Struggle of Geisha in Maintaining Her Pride as seen in Arthur Golden's Memoirs of a Geisha" seen from the perspective of structuralism. This research is limited on basic ideas that relate to the observation into three questions as follow: (1) how is geisha's life before World War II (2) how was the geisha struggle after World War II, and (3) how is geisha maintaining her pride before and after second world war. The objectives of this research were (1) to analyze Sayuri's life before World War II (2) to explain Sayuri's life after World War II, and (3) to study and explain the types of struggles in maintaining her pride by Sayuri as the main female character, to oppose and think of Sayuri's struggle to fight exploitation and significant meaning, and to find out and explain the depiction of Sayuri's struggle. The theory used is from Gough and Gautam about the structural analysis used to answer the purpose of this research. For the method of data analysis, the author uses systematic procedures with novel understanding and structural theory. Data collection techniques use documentation techniques in finding data that is relevant to the subject of analysis. The object of this research is a novel entitled Memoirs of a Geisha written by Arthur Golden in 1997 and the data are sentences related to the struggle of a woman found in the novel. Sayuri as the main female character in the novel represents women in general who can gain their independence and have a smart and brave attitude to take the important decisions in their life.
\end{abstract}

Keywords: Women's Struggle, Structural, Memoirs of a Geisha

(C) 2019Jurnal JILP

\section{INTRODUCTION}

Novel, "Memoirs of a Geisha", was written by Arthur Golden. Published in 1997 in the United States, it was a bestseller of the year. The unique life of a geisha above has been reflected by Arthur Golden more specifically in his novel entitled Memoirs of a Geisha. He wrote the memoirs of his friends who once ever served herself as a geisha. Arthur Golden was one of the greatest American novelist who has written many literary work such as Geisha
(1999), Die Geisha (2000), and Memoirs of a geisha that has been translated into 21 languages. Memoirs of a Geisha tells the story of a young girl, Chiyo, who is sold into the life of a geisha and her struggle as a geisha to find love. Tells the story of Chiyo Sakamoto, who is sold into a life of servitude by her parents when she is nine years old. Chiyo is taken in by the proprietress of a geisha house.

Chiyo resolves to become a geisha so that

Jurnal JILP (Jurnal Ilmiah Langue and Parole) Vol. 2 No. 2 (2019) ISSN : 2581-0804

This work is licensed under a Creative Commons Attribution-NonCommercial 4.0 International License. 
she may one day become a part of the Chairman's life. Chiyo, now a young woman, is taken under the wing of Mameha, head of a rival geisha house. Under Mameha's tutelage, the girl Chiyo becomes Sayuri, the most famous geisha in all Gion, Kyoto.

Sayuri, through her work as a geisha, is reunited with the Chairman, whom she has secretly loved since she was a girl, although she is led to believe he has no memory of who she was before she became a geisha. Her prosperous life is cut short by the outbreak of World War II and while the safety of Sayuri and Mameha is ensured by the Chairman, they must endure a life of hard labour. After the war, Sayuri is reunited with Mameha, and they become geisha once more.

A true geisha is a person of art. A geisha can be summarized as a person to "perform" arts. The geisha's identity consists in "performing" so called traditional Japanese art. In Japanese society some of Japanese women enter a unique profession named "geisha", a profession which makes their position quite different from woman in common. Geisha derived from a root word -geill which means art, and -shall which means a person who performs in Japanese language. The word consists of two kanji, 芸 (gei) meaning "art" and 者 (sha) meaning "person" or "doer". The most literal translation of geisha into English would be "artist," "performing artist," or "artisan." Another name for geisha is geiko (芸子), which is usually used to refer to an apprentice geisha from Kyoto (Mineko, 2002).

Geisha is a professional hostess who entertains guest through various performing art such as dancing traditional dance, singing and playing shamishen in teahouses called an Ochaya, their primary job is to make man feel warm, witty, and virile. Geisha study and perform several genres of shamisen, song, percussion, and dance, and are unique in the context of the traditional arts in Japan because they are multi- disciplinary artists in contrast to highly specialized professional musicians, dancers, or actors. (Foreman, 2008:1).
Geisha always wear kimono. Unlike a regular kimono, a geisha's kimono exposes her neckline, in Japanese culture, this is considered the most sensual part of a woman. The kimono is the most costly and important aspect of geisha's appearance. True geisha kimono must meet certain standards; they differ considerably than kimono worn by women who are not geisha, as well as from those worn by apprentices. For many years the world of the geisha, often referred to as the flower and willow world, has perplexed and intrigued people around the world. The most common image of a geisha is a white faced, red lipped, kimono clad and glorified prostitute, but in truth they are so much more (Moulton, 2009:3).

One of the most memorable aspects of the geisha is her makeup. However, a fully fledged geisha wears a minimal amount of make up; it is, in actuality, the apprentice who wears the full face of white make up on a regular basis. Makeup makes the geisha is more beautiful and make all people feel impressed. They have unique make-up because their make-up is different from the other women generally. Geisha has many styles of hair. It starts from the young geisha till becoming a full geisha.

Memoirs of a Geisha is an in interesting novel; there are four aspects that make this novel really interesting. The first is Memoirs of a Geisha has very much like Cinderella in Japan. There's the role of the beautiful servant girl, in which Ciyo is absolutely captivating; the gentle prince, a role that Watanabe nearly steals the show once again with; and the evil stepsister. The second aspect is novel, Arthur Golden wants to illustrate how women are subordinated and exploited in patriarchal society. Third, in this novel, Arthur Golden wants to say that women Right are not given but must be struggled for. The last, in this novel Arthur Golden wants to describe that in order to get their rights as human beings women should be smart and talented. From this point, Sayuri is interesting to be discussed from the life of a geisha before and after World War II. She is a woman in the late twentieth century who tries to survive in a very strict society by deciding to be a geisha. 


\section{RESEARCH METHODS}

The method of collecting data, the writer get the data from the novel itself. A library is a collection of sources of information. It provides physical or digital access to material, and may be a physical building or room, or a virtual space, or both. A library's collection can include books, periodical, manuscripts, films, maps, prints, document, microform, CDs, cassettes, videotapes, DVDs, Blu-ray Discs, e-books, audio books, database, and other formats.

In concern with library research, the writer takes the novel Memoirs of A Geisha by Arthur Golden as main data of this research. The writer also collects books and searching on internet as references of this writing and theories to solve the research problems that conveys in this thesis.

\section{A. Method of Analyzing the Data}

In analyzing the data, the writer uses structural method. According to Pradopo (2001:69). The researcher has role to explain literary work as a structure based on the elements that build them. From this quotation, structural method has functions to explain the intrinsic elements of literary work.

The procedure starts by reading the main source of research, which is the novel Memoirs of A Geisha by Arthur Golden. Then in order to have the audio visual understanding, the writer finds the movie Memoirs Of A Geisha. After understanding the story, the procedure moves to

\section{RESULTS AND DISCUSSION}

\section{A. Geisha's life before World War II}

In Memoirs of a Geisha, Sayuri as the main female character suffers from the exploitation since she was ten years old. The strong patriarchal culture in the society, the influence of capitalism system in Japan, and women's stereotype are the main causes of the exploitation cases.

According to Gallagher (2003), in the early of nineteenth century in Japan, geisha's performance was the most favorite entertainment for people. As a result, it stimulated the numerous of okiya (house of geisha training) business to educate the find the intrinsic elements in the novel, which are plot, theme, characters, setting of place, setting of time, and point of view. Next, the information received from data collection procedure is studied by limiting on the research of the intrinsic element, and also there is an extrinsic element such as psychology in the research. After the data are organized, the writing is composed based on standard of thesis writing.

\section{B. Technique of Collecting the Data}

The writer uses documentary thesis in collecting the data. This technique is attempted to trace the source of information in the form of document which are relevant to the object of the research. The writer uses reading the novel, searching on internet and watch the movie for collecting the data.

\section{Technique of Analyzing the Data}

The data analyzing procedures concern by interpreting the data. Structural technique has two functions which explain the internal factor of literature. The primary data is taken from novel itself, the writer tries to analyze it by using the information in form of quotations based on the novel itself. In doing this research, the writer starts by analyzing some intrisic elements of this novel, after that tries to find extrinsic element which becomes the basic of the problem that will be.

prospective young girls to be geisha entertainers. The training stages to be a geisha are very difficult and demand a very strong physic and psychological pressure. If a woman becomes a geisha, she will have no freedom to acquire her right and determine her own life. This case is what happens to Sayuri in Memoirs of a Geisha novel.

This case is what happens to Sayuri in Memoirs of a Geisha novel. She has suffered from the exploitations since she was a child until she has become a geisha. The kinds of exploitations which are found in the novel are divided into four categories: 


\section{Slavery}

Slavery has happened since long time ago due to the strong patriarchal system in the society and the influence of capitalism era in the early of eighteenth century all over the world. At that time, there were known two classes of the society: the bourgeoises and proletariats (Goran, 1991: 21).

In this novel, Sayuri is sold to the okiya, which is the place to educate the young girls to be the professional geisha. The okiya does not only educate the geisha but also employs them as maids before they are ready to learn about the art of being geisha. After getting their successful career as geisha, they will be the money machine who should earn a certains of money to the okiya. The kinds of slavery which are suffered by Sayuri are divided into three subcategories: being sold to the Okiya by her father, being given overload work in the Okiya, and being forced as a money machine in the okiya.

\section{Sexual Harassment}

Another form of exploitation experienced by Sayuri before world war II was sexual harassment. A long time ago, the society in the world assumed that geisha was a women who sold themselves as the common prostitute (Yoshimi, 1995). This perception is wrong because basically a geisha is an artist.

They had trained hard with a variety of traditional Japanese art skills, such as dancing, picking the shamisen (Japanese traditional guitar), making the art of conversation, doing the tea ceremony and so on. The kinds of sexual harassment which occur to Sayuri are divided into two sub-categories, first being suffered from mizuage auction and then being undressed by the Baron.

\section{Violence}

Either physical or psychological violence to women happens because of the women's stereotype in the society. Women's stereotype describes women as weak, powerless, and fragile figure. In Memoirs of a Geisha, Sayuri suffers from physical and psychological violences that are done by Hatsumomo, Mother and even Mameha her own adopted sister. The kinds of violence which are afflicted by Sayuri are divided into two sub-categories, first being beaten because of Hatsumomo's slander and then being forced to cut her leg by Mameha.

4. Subordination

Women do not have complete freedom to act and do their will as men's due to the strong patriarchal sytem. The limitations of women's freedom cover almost all aspects of life. The patriarchal system puts women as such less important figure, for example, in terms of getting job where women are not allowed to go out of home to work. It happens to Sayuri who her mobility is limited by Mother. Although Mother who governs the okiya is also a woman, she keeps treating Sayuri with strict regulation. It is caused by the patriarchal system that is entrenched on geisha tradition created by men.

The categories of women subordination reflected in Sayuri's character are divided in three sub-categories those are the limitation to go outside the Okiya, the limitation to choose the danna and the limitation to use the money from her work hard.

\section{B. Geisha's Life after World War II}

\section{Expressing Her Secret Love to the Chairman}

In geisha tradition, there is a strict rule for not falling in love with any men except in one condition, he is her danna. Geisha do not get married and sell their body like the common prostitute. The rule is only men with honour position and wealth that can have geisha as theirs.

When Sayuri was still 12 years old, she cried for her poor fate after Mother punished her to be a maid forever and made lost her opportunity to learn the art of being geisha. A good looking charismatic man came and asked her why she looked so sad. The man is the Chairman who is the founder of Iwamura Electric in Osaka which is the first company electric in Japan. At that moment, it was not common for a man to speak with a maid girl at the side of the road. The meeting is very imprinted Sayuri's mind until she is growing mature and it makes her mind is enlightened.

\section{Leaving the Okiya}

As a smart woman, Sayuri arranges a plan to gain her independence. She knows that if she continues staying in the okiya, Mother will always take advantages on her. The Chairman 
proposes himself to be Sayuri's danna to Mother. A danna ceremony is hold to mark their love relationship. Sayuri asks Mother to let her go from the okiya and lives with the Chairman in a luxurious house that has been purchased for her in northeastern Kyoto. Mother does not allow her at first, but Sayuri asks the Chairman to pay a certains of money each month to replace the revenues of the okiya after Sayuri is left.

3. Moving to New York and Opening a Japanese Tea House Business

In struggling life independence, women can do many things to reveal their capability. Women are not weak and foolish. They can break the stereotype if they have opportunity by society to do it. As represented in this novel, the last most important struggle of Sayuri's independence is her moving to New York. She has left her work as a geisha who is visiting from one tea house into another for entertaining and accompanying men or attending a party. Sayuri sees the opportunity to open a Japanese tea house business in the United States with her smart mind. She proposes her idea to the Chairman and the Chairman does agree with her proposal.

\section{Geisha's Struggle to Maintain Her Pride}

1. The Kinds of Sayuri's Struggles

Sayuri, the main female character in Memoirs of Geisha, is initially portrayed as a weak figure and does not have the power to fight against the exploitation. However, her experiences dealing with exploitation since she was a kid lead her on a consciousness that she deserves to get a better life practically no one owns her. Particularly after Sayuri is growing up, her mind becomes more open. She starts fighting for her dream to gain a freedom. Sayuri's struggles to fight against exploitation falls into seven categories, there are sneaking out from the okiya to meet her sister, trying to escape from the okiya, learning hard to be a geisha, and refusing Nobu's proposal to be her danna.

2. The Significant Meanings of Geisha's Struggles

Women's exploitation has apperead since many years ago since the society believed in patriarchal system. Women's roles in doing many activities such as in the field of job, politics, and education are limited caused by the strong patriarchal culture which is praticesed within the society. As a result, many people who do not agree and oppose women's exploitationreact to fight and stop women's exploitationpractise. This reaction is so called as feminism movement.

In the novel, Golden reveals women's problem that is the exploitation which occurs in geisha's life in Japan during the early nineteenth century. Golden also portrays some struggles that can be done by women in order to fight againts the exploitation taken by Sayuri, the main female character in the novel. Sayuri's struggles falls into seven categories, there are sneaking out from the okiya to meet her sister, trying to escape from the Okiya, learning hard to be a geisha, refusing Nobu's proposal to be her danna, expressing her secret love to the Chairman, leaving the Okiya and moving to New York and opening Japanese tea house business.

Through Sayuri's struggle, Golden shows some ways that can be done by women to overcome their problem. Furthermore, the struggles taken by Sayuri have two significant meanings because Sayuri as a woman and a geisha has survived successfully from women's exploitationfor over than 12 years by finally gaining her own independence.

3. The Portrayal of Sayuri's Struggles Represented in Memoirs of a Geisha

In examining and analyzing literary works, literary elements are needed by the reader to appreciate and interpret the story (Scott, 2004: 3). Furthermore, literary elements are used by the researchers to convey their message in their works. This is being the main reason why it is very crucial to develop an analysis of literary elements in literature study. Since this research concerns on feminism topic, it is important for the researcher to present an analysis of literary elements to distinguish between feminism analysis in literature study topic and feminism analysis in another topic of study.

According to Sugihastuti (2007), literary elements consist of some following aspects such as theme, plot, conflict and characterization. In his Memoirs of a Geisha work, Golden mainly uses two elements to 
portray Sayuri's struggles to fight against the exploitation in the novel. First, characterization, Sayuri's struggles are portrayed through the characterizatio. In this novel, Sayuri is described as smart and brave woman. Since she was a kid, she has done some struggles to make her life better than when she is only only a geisha. Sayuri's struggles are described in terms of her traits, actions, and speechs.

Second, plot, Sayuri's struggles are portrayed through the plot. The plot reveals the

\section{CONCLUSION AND SUGGESTIONS}

\section{A. Conclusions}

After analyzing Golden's Memoirs of a Geisha based on structural perspective focusing on Sayuri's struggles in maintaining her pride and how those are described in the novel by the author, and the significant meanings behind Sayuri's success in gaining her independence, the researcher concludes several points as follows:

1. Sayuri as the main female character shows her struggles for life independence.

2. Sayuri's struggles to maintaining her pride are portrayed in the novel by two literary elements: characterization and plot. The characterization is presented in her traits, actions and speeches. Meanwhile, the character conflict with herself and character conflict with her surrounding environments are presented in the plot.

3. Women's exploitation is caused by patriarchy system, the effect of conflicts that occur in the story. The conflict usually consists of three formats: character in conflict with one another, character in conflict with their surroundings environment and characters in conflict with themselves. In this novel, the conflicts are described by Golden as the character in conflict with herself and the character in conflict with her surrounding environment.

capitalism, and women's stereotype which are adopted in Arthur Golden's Memoirs of a Geisha. In the novel, women's exploitations are found into four categories: slavery, sexual harassment, violence, and subordination.

\section{B. Suggestions}

In writing this thesis, the writer wants to give suggestion :

1. For the readers in general, this thesis writing should be an inspiration in making writings related to theory.

2. The futher researcher can use the result of this research as a reference.

3. The Students

The writer hopes that the students can imitate the atitude of the main character, especially women, so they have enthusiasm to reach their goals. 


\section{Bibliography}

[1]A, Teeuw. 2010. Sastra dan Ilmu Sastra: Pengantar Teori Sastra. Jakarta: Dunia Pusat Jaya.

[2]Abrams, M.H., and Geoffrey Halt Harpham. 2009. A Glossary Literary Terms: Ninth Edition. Boston: Wadsworth Cengage Learning.

[3]A'ini, Qurratul. 2015. The Portrayal of Geisha's Life in Memoirs of A Geisha by Arthur Golden (mimetic approach) Vol.7(1). Jurnal Kajian Ilmiah. Surabaya: Universitas Pesantren Tinggi Darul 'Ulum.

[4]Barker, Chris. 2000. Cultural Studies, Theory, and Practices. London: Sage Publication.

[5]Bertens, K. 2008. Etika. Jakarta: PT. Gramedia Pustaka Utama.

[6]Bressler, Charles. 2011. Literary Criticism: An Introduction to Theory and

Practice (A Second Printing) (5th Edition). London: Longman.

[7]Coles, William H. 2018. Conflict in Literary Fiction.

https://www.storyinliteraryfiction.com/ess ays-on-writing/conflict-in-literary-fiction/. Accessed on December $03^{\text {rd }}, 2018$ at 14:23 PM.

[8]Dalby, Liza. 1983. Geisha. California: University of California Press.

[9]Foreman, Kelly M. 2008. The Gei of Geisha: Music, Identity and Meaning. London: Burlington VT.

[10]Gallagher, John. 2003. Geisha: A Unique World of Tradition, Elegance, and Art. USA: Sterling Publishing Co.

[11]Golden, Arthur. 1997. Memoirs Of A Geisha. New York: Vintage Book.

[12]Goodman, Douglas J \& George Ritzer. 2004. Teori Sosiologi Modern (Translated by Alimandan). Jakarta: Kencana.

[13]Gough, Noel. 2010. Structuralism. In Kridel, Craig (Ed.), The SAGE Encyclopedia of Curriculum Studies. New York: Sage Publications.

[14]Hood, Dave. 2010. How to Analyze Fiction. https://davehood59.wordpress.com/ 2010/01/28/how-to-analyze-fiction/.
Accessed on November $23^{\text {rd }}, 2018$ at 05:37 PM.

[15]Humm, Maggie. 2004. Into The Millennium:Feminist Literary Criticism. UK: University of East London.

[16]Iwasaki, Mineko. 2002. Geisha, A life. New York: Atria Books.

[17]Kennedy, XJ. 1983. An Introduction to Fiction. Canada: Lttle, Brwon \& Company.

[18]Millett, Kate. 2000. Sexual Politics. USA: Illinois Press

[19]Moulton, James R. 2009. Geisha Behind the Painted Smile. Wales: Honors Research Advisory Seminar.

[20]Putra, Dhimas Citra Permana. 2016. Human Needs in Arthur Golden's Memoirs Of A Geisha. Surabaya: English Literature, Faculty of Languages and Arts, State University of Surabaya.

[21]Pradopo, Rahmat Djoko. 2001. Metodologi Penelitian Sastra. Yogyakarta: Hanindita Ghasa Widia.

[22]Ratnasari, Ninda Arum Rizky. 2014. Sayuri's Struggles In Confronting Geisha's Exploitation In Arthur Golden's Memoirs Of A Geisha: A Feminist Criticism. Yogyakarta: Yogyakarta State University.

[23]Selden, Raman and Widdowson, Peter. 2005. A Reader's Guide to Contempory Literary Theory fifth edition. UK: Pearson Education Limited.

[24]Sofia, Riza. 2011. "Analisis Ketidakadilan Gender Dalam Novel Memoirs Of A Geisha Karya Arthur Golden". Jember: Universitas Jember.

[25]Sugihastuti. 2007. Teori Apresiasi Sastra. Yogyakarta. Pustaka Pelajar.

[26]Therborn, Göran. 1991. Why Some Peoples are More Unemployed than Others. UK: Verso Books.

[27]Yoshimi, Yoshiaki. 1995. Comfort Women. Sexu-al Slavery in the Japanese Military during world War II. Trans by suzanne Obrien. New York: Columbia University Press. 